\title{
Dividend payout policy, family control, and institutional investors in an emerging country:The case of Mexico
}

\author{
Política de pago de dividendos, control familiar e inversionistas institucionales \\ en un país emergente: el caso de México
}

\author{
Humberto Valencia Herrera*, Felipe Javier Ruiz Rivera \\ Instituto Tecnológico y de Estudios Superiores de Monterrey, México
}

Received October 27, 2017; accepted November 21, 2018

Available online July 29, 2019

\begin{abstract}
The dividend payout ratio and its volatility in firms listed on the Mexican Stock Exchange from the second quarter of 2009 to the first quarter of 2013 relate to corporate governance aspects. A structural equations model found that institutional investors avoid firms with high family intervention and prefer market risk despite greater volatility in dividend payouts. Similarly, the dividend payout volatility and market risk are positively related. Moreover, dividend payout is smaller in firms with high family intervention in management. Companies with a strong family control smooth their dividend payout and have a smaller number of institutional investors.
\end{abstract}

JEL codes: G35, G32, G30

Keywords: Dividend policy; Corporate governance; Family control

\section{Resumen}

La razón de pago de dividendos y su volatilidad en las empresas que cotizan en la Bolsa Mexicana de Valores desde el segundo trimestre de 2009 hasta el primer trimestre de 2013 se relacionan con aspectos de gobierno corporativo. Un modelo de ecuaciones estructurales encontró que los inversionistas institu-

\footnotetext{
${ }^{*}$ Corresponding author

E-mail address: humberto.valencia@tec.mx (H. Valencia Herrera)

Peer Review under the responsibility of Universidad Nacional Autónoma de México.

http://dx.doi.org/10.22201/fca.24488410e.2019.1762

0186- 1042/C2019 Universidad Nacional Autónoma de México, Facultad de Contaduría y Administración. This is an open access article under the CC BY-NC-SA (https://creativecommons.org/licenses/by-nc-sa/4.0/)
} 
cionales evitan las empresas con una alta intervención familiar y prefieren el riesgo de mercado a pesar de la mayor volatilidad en el pago de dividendos. Del mismo modo, la volatilidad del pago de dividendos y el riesgo de mercado están positivamente relacionados. Además, el pago de dividendos es menor en empresas con alta intervención familiar en la gestión. Las empresas con un fuerte control familiar suavizan sus pagos de dividendos y tienen un número menor de inversores institucionales.

Código JEL: G35, G32, G30

Palabras clave: Política de dividendos; Gobierno corporativo; Control familiar

\section{Introduction}

The celebrated Miller-Modigliani theorem states that in a frictionless market, the dividend and the financing policies are irrelevant (Miller \& Modigliani, 1961). However, there is ample literature that relates dividend policy with profitability and corporate governance issues, among others. In emerging markets, such as those from Mexico and Latin America, the dividend payment policy has characteristics very different from those in the US market, where there are better corporate governance systems and concerning the rights of institutional and minority investors, that has hampered the development of financial markets.

A relevant issue in the corporate finance literature is the separation of ownership and control (Jensen \& Meckling, 1976). That is the dividend policy results from a situation in which the interests of the different participants in the company conflict because the resources of the enterprise are finite, there is asymmetry of information and different attitudes to the risk of the players (Agrawal \& Mandelker, 1987; Mehran, 1992). On the other hand, dividends also transmit information to the market (Miller \& Rock, 1985). Where there are limited information and little protection for minority investors, dividends allow the market to be informed of the treatment of minority investors in the company (Lin, 2002; La Porta, López-de-Silanes, Shleifer, \& Vishny, 2002). Dividends also make it possible to reduce the funds available in the company, which avoids misuse (Jensen, 1986).

In particular, the dividend payout policy relates to the profitability of the firms in Latin America. For example, Benavides, Berggrun, and Perafan (2016) find that the dividend payout increases with profitability and decreases with past indebtedness. However, other studies found contradictory evidence. For example, Grullon, Michaely, and Swaminathan (2002) find that profits do not increase after a dividend increase and, for dividend decreasing firms, recover, rather than decline. 
The quality of the corporate control affects the payment of dividends. Manos (2003), using the Rozeff (1982) model found that dividends help reduce agency costs in poorly controlled firms. On the other hand, in companies where majority investors are dominant, they may have incentives to extract profits from minority shareholders, paying fewer dividends (Bena \& Hanousek, 2006). For Latin America, González, Guzmán, Pombo and Trujillo (2015) discuss that in closely held firms, minority shareholders press for dividends if they perceived a situation promoting wealth expropriation. In the study of 458 Colombian companies, they find that family involvement in management of the firm does not bear upon the dividend policy. However, family engagement in ownership and control impacts dividend policy negatively. Family involvement through a more than normal board representation bears upon dividend policy positively. Benavides et al. (2016) also find that the dividend payout ratios are higher the better corporate governance in the country. If the corporate government is appropriate in the country, the speed at which the firms adjust their dividends to the profitability level is lower. Better governance also results in more smoothing of the dividends.

Another reason for small firms to have lower dividend payout ratios than large firms is that they have higher transaction costs to raise funds externally (Holder, Langrehr, \& Lawrence Hexter, 1998). They are less diversified on production and distribution, thus are riskier and with more financing restrictions (Behr \& Güttler, 2007). They are also family firms that reduce the payment of dividends to accumulate cash because they have a precautionary motive to inherit wealth to future generations (Durán, Belén Lozano, \& Yaman, 2016). They have a strategic perspective more than the short-term view, which is in accord with recent research that points out that holding cash is more a strategic response than an anti-cyclical response to outside factors (Ang \& Smedema, 2011).

The family relationships of the Chief Executive Officer (CEO) with other board members can affect not only the management of a corporation, but also several other corporate policies, including the dividends. Among the reasons are a better surveillance of the organization and alignment of management's objectives with those of the principal shareholders because family checks act as substitutes for corporate controls and dividend policy. Little research has been done on how the dividend payout volatility relates to the governance of an organization, specifically with a CEO's family ties with other board members or the presence of institutional investors. The family relationships can affect not only the dividend payout ratio but also its volatility. This study uses factor analysis and a structural equations approach to analyze these issues.

Concentrated ownership can result in a lower payout of dividends because there is less needing to reward other shareholders. Like other emerging countries with a French-origin and civil legal system, Mexican corporations show highly concentrated ownership (Valencia Herrera, 2009). According to Chong, Guillen, and Lopez-de Silanes (2009), except for Chile, 
which has strong shareholder rights, all Latin American countries in their sample have higher ownership concentration than the global mean. After Greece and Colombia (each with 68\%), Mexico had the third-largest ownership concentration level in the world (67\%). In sum, Mexico has unusually high ownership concentration, possibly as an adaptation to weak legal protection (Chong et al., 2009). Besides, Rozeff (1982) observes that insiders with significant stock ownership prefer small dividends to lower the taxes liability on capital gains. Another hypothesis suggests that weak corporate governance in businesses where management has a high ownership stake contributes to the expropriation of minority shareholders, who receive reduced dividends.

A greater number of external investors can improve corporate governance and firms' financial performance. According to La Porta, López-de Silanes, Shleifer, and Vishny (2000), better corporate governance results in a lower probability of expropriation by controlling shareholders. So, investors are more willing to finance businesses at a reduced cost, which can increase returns and dividends. In Mexico, Chong et al. (2009) found that the market rewards firms with good corporate governance by lowering their costs of capital, which provides better returns to their investors. Gompers, Ishii, and Metrick (2003) observed a positive effect from adequate corporate governance on operating performance in other countries.

The study after this introduction is organized as follows. The second section reviews primary theories and develops hypotheses. The third section discusses the data, methodology, and variables. The fourth section analyzes the results. The fifth section provides conclusions.

\section{Hypotheses development}

Different theories explain the connections between variables. This section explains how they relate to the research hypotheses.

\section{Relation between the dividend payout ratio and its volatility}

A positive relation exists between the dividend payout ratio and its volatility, that is, the higher the dividend payout ratio, the higher is its volatility. This relation is analogous to the one between risk and return in the efficient frontier from Markowitz's (1952) portfolio selection theory. It is also similar to the relation between returns and systematic risk in the security market line of the capital asset pricing model (CAPM) of Mossin (1966), Lintner (1965), and Sharpe (1964).

\section{Institutional investors avoid firms with large family intervention}

Institutional investors avoid investing in companies with large family intervention because family firms accentuate socioemotional wealth (See, for example Berrone, Cruz, \& Gomez-Mejia, 2012), which aggravates possible expropriation from non-controlling shareholders, such 
as institutional investors (Fernando, Schneible, \& Suh, 2014). Another likely reason is that such firms pay lower dividends than others.

\section{Institutional investors prefer market risk}

Institutional investors with stock market benchmarks are attracted to highBeta stocks. Iwasawa and Uchiyama (2014) stated that the Beta anomaly reflects a preference for high-Beta securities by institutional investors looking to beat a benchmark. In the case of the Japanese market, this is mainly the result of foreign investment (Iwasawa \& Uchiyama, 2014). This phenomenon can explain the well-known fact that a high-Beta stock is linked with a small alpha when measured with either the CAPM or with the Fama-French threefactor model (Black, Jensen, \& Scholes, 1972; Frazzini \& Pedersen, 2014). Furthermore, Demsetz and Lehn (1985) argued that substantial risk can disincentivize insiders to have significant ownership in a company because high return variability can cause abrupt changes in personal wealth. As a result, outsiders, such as institutional investors, will have greater ownership in such firms.

The previous hypotheses are not necessarily a consensus. For example, Demsetz (1983) asserted that companies with more risk are more difficult to control externally. Therefore, it is important to concentrate ownership in board members and management, which largely excludes outsiders. Chen and Steiner (1999) argued that it is a non-linear relationship. For companies with minimal systematic risk, a positive correlation exists between its Beta and inside ownership, based on a reduction of the agency conflicts between shareholders and management. However, if the systematic risk is high, a negative correlation exists.

\section{Free cash flow hypothesis}

The free cash flow hypothesis refers to a negative relation between the dividend policy and insider ownership. According to Jensen (1986), higher dividend payments reduce the discretion of management and the agency conflicts inside a firm. A business with higher insider ownership may have better corporate government (Almazan, Hartzelly, \& Starks, 2005), without the need to pay high dividends. The payout ratio and dividends will be lower in family firms. This justifies a negative relation between the dividend payout ratio and inside ownership because they are substitutes. An alternate theory is that the family group controlling the firm expropriates other shareholders. Bena and Hanousek (2006) observed this in Czech companies. As a result, family firms will tend to have lower dividend payout ratios.

\section{Hypothesis of irregular dividend payout ratios with more institutional investors}

The dividend payout ratio is more uneven at companies with more institutional investors compare with companies with substantial family control, which tend to have fewer institutional investors and smoother dividend payout stream. 
Free cash flow hypothesis regarding volatility

The free cash flow hypothesis regarding volatility refers to the direct link between volatility in dividend payout ratios and systematic risk of the firm, i.e., that the standard deviation of the dividend payout ratios reflects the company's Beta.

\section{Smoothing the dividend payout ratios in companies with strong family control}

Substantial family control of a business evens out dividend payout ratios. Treynor and Black (1976) proposed that companies with insider control provide less return variability because the management, whose human capital and investment portfolio may not be we1l-diversified, is risk-averse. Therefore, they will be interested in reducing business risk and smoothing dividends. Accordingly, if the $\mathrm{CEO}$ has related relatives on the board, the volatility of dividend payout ratios will be lower.

\section{Methodology and data}

Structural equations modeling (SEM) is a statistical technique that combines statistical data and qualitative, causal assumptions. It was formally defined by Pearl (2000), with the use of counterfactuals calculus. In SEM modeling, two principal components are distinguished: the structural model and the measurement model. Factor analysis, which includes the measurement part finds potential dependencies between exogenous and endogenous variables. Path diagrams usually include the structural part. The study focuses on results from the factor analysis .

A few corporate finance studies employ SEM. For example, Azim (2012) reports a study that uses SEM to analyze to what extent different monitoring mechanisms: the board, shareholders, and independent auditors substitute (i.e. with a negative covariance) or complement (with a positive covariance) each other. This study finds different cases where these mechanisms are either complements or substitutes.

Economatica is the data source for dividends and stock prices. To have an estimation of the volatility of the dividend payout ratios, average and standard deviation of dividend payout ratios were estimated from unseasoned quarterly data starting in the second quarter of 2009 and finishing in the first quarter of 2013. Dividend payout is the ratio of dividends to earnings after taxes in each quarter. Seventy-two firms in the original sample paid dividends in this period. The sample excluded observations with negative earnings after taxes. Beta comes from a linear regression of the quarterly returns of the stock on the ones of the Total Return Index (IRT in Spanish) of the Mexican Stock Exchange in the period of the second quarter of 2009 and finishing the first quarter of 2013. Only 136 firms quoted in this exchange during the period of the study. The source for the CEOs'family ties with other board members is the 
2012 Mexican Stock Exchange annual company report filings. If the report was unavailable, the previous year filling, till 2010, was used. Moreover, the sample only included companies that paid dividends at least twice during the study period, which was necessary to estimate the volatility. The study also excludes outliers whose average dividend payout was larger than five in the period of study. Sixty-nine firms satisfy all these requirements. Information about the number of institutional stock-holders is from Bloomberg at the end of 2012. The study considers that there is a family tie between the CEO and a Board Member if any the first or the second last name of the CEO was the same as the first or second last name of any other Board Member. The Board Members in the section of Managers and Stockholders in the Annual Financial Report Filling at Bolsa Mexicana de Valores was used to identify the CEO's family ties. The study assumes that CEO's family ties and the number of institutional stock-holders was constant during the period of the study. Table 1 shows basic statistics of the variables. The sample also excluded companies with no information about either institutional investors or the family relationships of the CEO in the board. As a result, the final sample comprised 62 companies. The period of the study, the second quarter of 2009 to the first quarter of 2013, corresponds to a period of steady recovery form the 2008 Great Recession.

The final sample of companies is distributed according to the Economatica Sector Classification as trade (23\%), food and beverages (20\%), telecommunications (13\%), construction (9\%), non-metallic minerals (9\%), transportation services (7\%), agriculture and fishing (4\%), basic and fabrication metallics (2\%), electric energy (2\%), finance and insurance (2\%), industrial machinery $(2 \%)$, mining $(2 \%)$, vehicles and parts $(2 \%)$, and others $(11 \%)$.

The study considers the following variables: Ceofam is equal to one if the CEO has a family relationship with a board member or zero, otherwise. Instholders is the number of institutional investors in the firm. Divmu is the average quarterly dividend payout ratio. Divsigma is the standard deviation of the quarterly dividend payout ratio. Moreover, Beta is the sensitivity of the stock's returns to those of the IRT.

\section{Analysis of results}

This section has four parts. The first one analyzes the correlation among variables, the second discusses results using factor analysis, the third fits the structural equations model, and the fourth examines the proposed hypotheses in light of prior results.

Table 1 shows the basic statistics of the considered variables: the number of observations, the mean, the standard deviation, the skewness, the kurtosis, the minimum, and the maximum of each variable. The study includes 69 firms in which observations of the average and standard deviation of the dividend payout ratio, the beta and the family relations of the CEO were 
available. Only 62 firms included information about the number of institutional stockholders. All variables are skew to the right, that is, its skewness is positive. Similarly, all variables are leptokurtic (kurtosis greater than 3), except Ceofam, which is platykurtic.

Table 1

Basic statistics of the variables

\begin{tabular}{|c|c|c|c|c|c|}
\hline Statistics & Divmu & Divsigma & Beta & Ceofam & Instholders \\
\hline $\begin{array}{l}\text { Number of } \\
\text { observations }\end{array}$ & 69 & 69 & 69 & 68 & 62 \\
\hline Mean & 1.3511 & 1.0395 & 0.6061 & 0.4265 & 66.5968 \\
\hline $\begin{array}{l}\text { Standard } \\
\text { deviation }\end{array}$ & 1.0478 & 1.1773 & 0.6401 & 0.4982 & 70.3069 \\
\hline Skewness & 1.2994 & 2.6048 & 0.4511 & 0.2974 & 1.2034 \\
\hline Kurtosis & 4.7338 & 10.7563 & 3.7450 & 1.0884 & 3.7999 \\
\hline Minimum & 0.0184 & 0.0084 & -1.0006 & 0 & 0 \\
\hline Maximum & 4.9891 & 6.4659 & 2.7270 & 1 & 272 \\
\hline
\end{tabular}

Divmu and Divsigma are respectively the average and the standard deviation of the dividend payout ratio. Beta is the sensitivity of a stock's returns to those of the IRT. Ceofam is one if the CEO has a family relationship with a board member or zero otherwise. Instholders is the number of institutional stockholders. Source: Own elaboration.

\section{Correlation of variables}

From the correlation matrix in Table 2, the correlations between Divmu and Divsigma, Divmu and Ceofam, Divsigma and Beta, Divsigma and Instholders, Beta and Instholders, and Ceofam and Instholders are statistically significant. They relate to the proposed hypotheses as follows: The positive correlation (0.6693) between Divmu and Divsigma supports the hypothesis of a relation between dividend payout and its volatility. The negative correlation $(-0.2913)$ between Divmu and Ceofam supports the free cash flow hypothesis. The positive correlation $(0.2978)$ between Divsigma and Beta supports the free cash flow hypothesis regarding volatility. The positive correlation (0.3426) between Divsigma and Instholders supports the hypothesis of irregular dividend payout ratios with more institutional investors. The positive correlation $(0.4275)$ between Beta and Instholders supports the hypothesis that institutional investors prefer market risk. The negative correlation $(-0.3696)$ between Ceofam and Instholders supports the hypothesis that institutional investors avoid firms with large family intervention. 
Table 2

Correlation between variables

\begin{tabular}{|c|c|c|c|c|c|c|c|c|}
\hline & Divmu & & Divsigma & & Beta & & Ceofam & Instholders \\
\hline Divmu & 1.0000 & & & & & & & \\
\hline Divsigma & 0.6693 & $*$ & 1.0000 & & & & & \\
\hline Beta & 0.1597 & & 0.2978 & $*$ & 1.0000 & & & \\
\hline Ceofam & -0.2913 & $*$ & -0.1259 & & -0.0556 & & 1.0000 & \\
\hline Instholders & 0.1061 & & 0.3426 & * & 0.4275 & $*$ & $-0.3696 *$ & 1.0000 \\
\hline
\end{tabular}

*The probability of the zero-correlation hypothesis is $5 \%$ or lower. See variables in Table 1 . Source: Own elaboration.

\section{Factor analysis}

For an exploratory analysis of the variables, this study uses factor analysis. Factor analysis is a statistical method employed to analyze variability among correlated, observed variables noting possible latent unobserved factors. In this technique, linear combinations of unobserved factors, plus error terms, are used to model the observed factors. Each factor captures a portion of the total variance in the observed variables. Factors that explain more of the variation in the observed variables are selected.

Table 3 shows the results of a factor analysis based on an orthogonal rotation with the varimax method proposed by Kaiser (1958), using standardized initial factor loadings for each variable. Factor One mainly relates to dividend policy: the association between high dividends and high dividend volatility. Factor Two relates to institutional holders and volatility: the association among large number of institutional holders, strong betas and high volatility of dividends. Factor Three contrast institutional holders against family relations: Many institutional holders contrast with the family relations of the CEO with other board members. Factor One strongly and positively relates to Divmu and Divsigma. Factor Two strongly and positively relates to Instholders, Beta, and Divsigma. Factor three strongly and negatively relates with Ceofam and strongly and positively relates with Instholders and Divmu. Uniqueness refers the proportion of the shared variance for the variable not associated with the factors. From the uniqueness column, the proposed factors almost entirely explain the variances of Divsigma and Divmu because the uniqueness representations of these variables are relatively small, 0.3543 and 0.3712 , respectively. In contrast, Beta, Ceofam, and Instholders have relatively large uniqueness representations of $0.6939,0.6611$ and 0.4930 , respectively, which show that the proposed factors explain most of their variations. 
Table 3

Factor analysis of the variables with an orthogonal rotation

\begin{tabular}{lcccc}
\hline Variable & Factor 1 & Factor 2 & Factor 3 & Uniqueness \\
\hline Ceofam & -0.1364 & -0.1237 & -0.5522 & 0.6611 \\
Instholders & 0.0855 & 0.6081 & 0.3604 & 0.4930 \\
Beta & 0.1509 & 0.5310 & 0.0367 & 0.6939 \\
Divmu & 0.7626 & 0.0474 & 0.2122 & 0.3712 \\
Divsigma & 0.7245 & 0.3403 & 0.0702 & 0.3543 \\
\hline
\end{tabular}

*See variables in Table 1 .

Source: Own elaboration.

\section{Structural equation model}

The proposed structural equation model includes the following three equations: Instholders as a function of Ceofam and Beta, Divmu as a function of Ceofam, and Divsigma as a function of Instholders. The model assumes that Divmu and Divsigma can have a non-zero correlation.

$$
\begin{aligned}
\text { Instholders }_{i}= & a_{0}+a_{1} * \text { Ceofam } \\
\text { Divmu }_{i}= & b_{0}+b_{1} * \text { Ceofam } \\
i & +e_{2, i} \\
\text { Divsigma }_{i}= & c_{0}+c_{1} * \text { Instholders }_{i}+e_{1, i} \\
& e_{2, i} \text { and } e_{3_{i}} \text { can be correlated }
\end{aligned}
$$

In the Equation System 1, the first equation corresponds to the hypothesis that the number of institutional holders (Instholders) is related negatively with a CEO with family relations with other board members (Ceofam) and that the number of institutional holders (Instholders) is positively related with systematic risk (Beta). The first relation was previously corroborated by the strong negative correlation between Ceofam and Instholders in Table 2, and the opposite signs and relatively large coefficients of Ceofam and Instholders in Factor 3 in Table 3. The second relation was corroborated by the strong positive correlation between Instholders and Beta in Table 2 and the same sign of the coefficient of Instholders and of Beta in Factor 2 in Table 3. The second equation corresponds to the hypothesis that the size of the dividend (Divmu) is negatively related with a CEO with family relations in the board (Ceofam). The hypothesis was corroborated by the strong negative correlation between Ceofam and Divmu in Table 2 and the opposite signs of Ceofam and Divmu in Factor 3 in Table 3. The third equation refers to the hypothesis that the volatility of the dividends (Divsigma) positively relates with investment of institutional investors (Instholders). The relation was previously corroborated by the strong positive correlation between Divsigma and Instholders in Table 2 and the same sign and relatively large coefficients of Instholders and Divsigma in Factor 2 in Table 3.

Table 4 shows the final model of structural equations. In Equation One, a CEO with family relationships on the board is related negatively to the participation of institutional holders, 
Ceofam has a negative coefficient, -49.0213 . Institutional investors and a CEO with family links on the board are substitutes for controlling a company. From the same equation, the participation of institutional stockholders is related to large Betas. Beta has a positive coefficient, 43.7562; that is, institutional holders prefer firms with high systematic risk. From the second equation, the presence of a CEO with family relationships in the board is negatively related to the payment of dividends. Ceofam has a negative coefficient $(-0.6157)$ in the equation. Dividend policy acts as a substitute for the presence of a CEO with family relationships on the board and imposes discipline in a firm. From the third equation, a large participation of institutional holders is related to a high volatility in the dividend payout ratios. Companies with more institutional holders have higher and more volatile dividend payout ratios. These companies also have a lower probability of a CEO having family relationships on the board. The relation probably is because businesses with a CEO with family relationships on the board smooth the dividend payout, a practice that is less frequent in firms dominated by institutional shareholders. Instholders have a statistically significant coefficient of 0.0060 in the Divsigma equation. The covariance between the average dividend payout ratio and its standard deviation is 0.7970 , which is statistically different from zero. Figure 1 also illustrates relations in the structural model.

Table 4

Equations in the structural model

\begin{tabular}{|c|c|c|c|}
\hline Variable & Coefficient & Standard Error & $\mathrm{Z}$ \\
\hline \multicolumn{4}{|c|}{ Equation: Instholders } \\
\hline Ceofam & -49.0213 & 15.0105 & $-3.27 * * *$ \\
\hline Beta & 43.7562 & 11.3837 & $3.84 * * *$ \\
\hline Constant & 58.6563 & 12.4289 & $4.72 * * *$ \\
\hline \multicolumn{4}{|c|}{ Equation: Divmu } \\
\hline Ceofam & -0.6157 & 0.1882 & $-3.27 * * *$ \\
\hline Constant & 1.6078 & 0.1490 & $10.79 * * *$ \\
\hline \multicolumn{4}{|c|}{ Equation: Divsigma } \\
\hline Instholders & 0.0060 & 0.0015 & $3.92 * * *$ \\
\hline Constant & 0.6534 & 0.1765 & $3.70 * * *$ \\
\hline \multicolumn{2}{|c|}{ Covariance } & e.Divmu & e.Divsigma \\
\hline \multicolumn{2}{|c|}{0.7970} & 0.1757 & $4.53 * * *$ \\
\hline
\end{tabular}

The model includes three equations: Equation 1 relates Ceofam and Beta to Instholders, Equation 2 relates Ceofam to Divmu, and Equation 3 relates Instholders to Divsigma. The last row shows the covariance between error terms from equations Divmu and Divsigma. Cons refers to the constant coefficient. See other variables in Table 1. ***Statistically significant at 99 percent. Source: Own elaboration. 


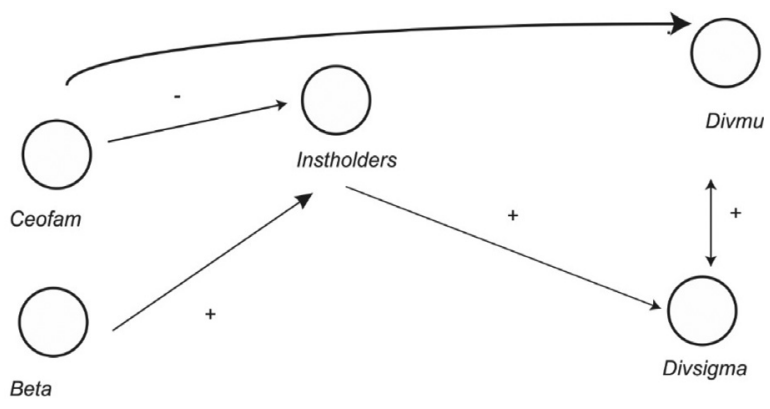

Figure 1. Structural relations

Source: Own elaboration.

\section{Support for the hypotheses}

The following discussion focuses on the support that the correlation analysis, the factor analysis, and the fitted structural model give to the research hypotheses.

\section{Relation between the dividend payout ratio and its volatility}

The results support the hypothesis of a positive relation between the dividend payout ratio and its volatility. The correlation between Divmu and Divsigma is statistically significant and positive (0.6693). In the factor model, in factor one, Divmu has 0.7626 and Divsigma has 0.7245. In the structural model, the covariance between errors in the equations of Divmu and Divsigma is positive and statistically significant (0.7970). The positive correlation between the dividend payout ratio and its volatility suggest that it can be a clientele effect based on investors' risk aversion, similar to the well-known positive relation between risk and return found in different finance models (Markowitz, 1952; Sharpe, 1964).

\section{Institutional investors avoid firms with large family intervention}

Evidence supports the hypothesis that institutional investors avoid companies with major family intervention. The correlation between Ceofam and Instholders is negative and statistically significant (-0.3696). In all three principal factors of the factor model, these variables have loadings with different signs. They are large in factor three, with loadings -0.5522 and 0.3604 , respectively. Similarly, in the Instholders equation of the structural model, the coefficient of Ceofam is negative and statistically significant (-49.0213).

\section{Institutional investors prefer market risk}

The results support the hypothesis that institutional investors prefer market risk. The correlation between Instholders and Beta is positive and statistically significant (0.4275). In the factor model, the three principal factors have the same sign for these variables. They are 
larger in factor two of the factor model 0.6081 and 0.5310 . In the Instholders equation of the structural model, Beta has a positive statistically significant coefficient (43.7562). These results are similar as those found by Iwasawa and Uchiyama (2014) for the Japanese market. The evidence can also be interpreted to mean that insiders prefer less risk, as proposed by Demsetz and Lehn (1985).

\section{Free cash flow hypothesis}

The findings support Jensen's (1986) free cash flow hypothesis. Here, the correlation between Ceofam and Divmu is negative and statistically significant (-0.2913). In the factor model, the loadings of these variables in the three principal factors have different signs, with large loadings in factor three of -0.5522 and 0.2122 , respectively. In the Divmu equation of the structural model, Ceofam has a statistically negative coefficient (-0.6157). For Mexico, the results do not exclude a possible expropriation of outside shareholders in firms with high family intervention, such as the one observed by Bena and Hanousek (2006) in Czech companies.

\section{Hypothesis of irregular dividend payout ratios with more institutional investors}

The evidence supports the hypothesis of irregular dividend payout ratios with more institutional investors. The correlation between Instholders and Divsigma is positive and statistically significant (0.3426). In the factor analysis, the loadings of these variables are high and have the same sign: 0.6081 and 0.3403 , respectively, in factor two. In the Divsigma equation of the structural model, the coefficient of Instholders is positive and statistically significant $(0.0060)$.

The results support the free cash flow hypothesis regarding volatility. The correlation between Beta and Divsigma (0.2978) is positive and statistically significant. In factor two of the factor model, the loadings of these variables have the same sign and are large, 0.5310 and 0.3403 , respectively. In the structural model, the relation between the variables is indirectly positive and statistically significant because in the Instholders equation, the Beta coefficient is positive and statistically significant (43.7562), and in the Divsigma equation, the Instholders coefficient is also positive and statistically significant $(0.0060)$. Thus, because its positive relation with institutional investors in the structural model, market risk positively relates to the volatility of the dividend payout ratio.

\section{Smoothing the dividend payout ratios in companies with strong family control}

The evidence for the hypothesis of smoothening dividend payout ratios in companies with strong family control is mixed. Correlation between the variables Ceofam and Divsigma is negative, but not statistically significant (-0.1259). In the factor model, loadings for these variables have opposite signs all three principal factors, but they are small. In the structural 
model, the evidence is indirect, derived from the presence of institutional investors. In the Instholders equation, the Ceofam coefficient is negative and statistically significant (-49.0213). In the Divsigma equation, the Instholders coefficient is positive and statistically significant (0.0060). So, firms with strong family control smoothen dividend payout ratios because they have a smaller number of institutional investors.

\section{Conclusions}

Family ties of the CEO with other board members and the presence of institutional investors have important implications for a firm's dividend policy.

Institutional investors would rather avoid companies with a CEO family related to other board members, possibly because it can increase the probability of wealth expropriation to outsiders.

Dividend payout ratios are lower in a firm where the CEO is related to other board members. One explanation for this is that family businesses have fewer agency conflicts and less need for a high dividend payout policy as a control mechanism.

Dividend payout ratios are smaller in firms where a family can control them, such as when a CEO is related to other board members. The volatility of the dividend payout ratio is positively correlated with the presence of institutional investors.

Analogous to the risk and return relation in stocks, the dividend payout ratio and its volatility are positively correlated, which can be a clientele effect.

In summary, institutional investors who require a large dividend payout ratio and a CEO with family ties to other board members are substitutes for business control. If institutional investors demand a large dividend payout, its volatility can be large too.

Another result is that institutional investors prefer high Beta-firms, possibly because of market benchmarks in their portfolios. The evidence does not support the hypothesis that highly risky businesses are harder to control so that they will have less external investors, such as institutional ones, and more internal ones, such as family members.

A better understanding of dividend policies and the extent to which family control matters in emerging and civil law countries requires further analysis.

\section{Acknowledgements}

The authors would like to thank the comments from participants of the FIMEF Inernational Conference, the financial support of Tecnológico de Monterrey, and Enago for the English language review. 


\section{References}

Agrawal, A. \& Mandelker, G. N. (1987) Managerial incentives and corporate investment and financing decisions, Journal of Finance, 42 (4), 823-837 http://doi.org/10.1111/j.1540-6261.1987.tb03914.x

Almazan, A., Hartzelly, J., \& Starks, L. (2005). Active institutional shareholders and costs of monitoring. evidence from executive compensation. Financial Management., 34 (4), 5-35. http://doi.org/10.1111/j.1755053X.2005.tb00116.X

Ang, J., \& Smedema, A. (2011). Financial flexibility: Do firms prepare for recession? Journal of Corporate Finance, 17 (3), 774-787. http://doi.org/10.1016/j.jcorpfin.2011.02.001

Azim,M.I.(2012).Corporate governance mechanisms and their impact on company performance: Astructural equation model analysis. Australian Journal of Management, 37 (3), 481-505. http://doi.org/10.1177/0312896212451032

Behr, P. \& Güttler, A. (2007) Credit Risk Assessment and Relationship Lending: An Empirical Analysis of German Small and Medium- Sized Enterprises, Journal of Small Business Management, 45 (2), 194-213, http://doi. org/10.1111/j.1540-627X.2007.00209.x

Bena, J., \& Hanousek, J. (2006). Rent extraction by large shareholders evidence using dividend policy in the Czech Republic. The Center for Economic Research and Graduate Education, Academy of Sciences of the Czech Republic, Economic Institute Working Paper Series, 291, 1-50. Retrieved March 23th, 2017 from http://www. cerge-ei.cz/pdf/wp/Wp291.pdf

Benavides, J., Berggrun, L., \& Perafan, H.. (2016). Dividend payout policies: Evidence from Latin America. Finance Research Letters, 17 (1), 197-210. http://doi.org/10.1016/j.frl.2016.03.012

Berrone, P., Cruz, C., \& Gomez-Mejia, L. R. (2012). Socioemotional wealth in family firms, theoretical dimensions, assessment approaches, and agenda for future research. Family Business Review, 25 (3), 258-279. http:// doi.org/10.1177/0894486511435355

Black, F., Jensen, M. C., \& Scholes, M. (1972). The capital asset pricing model: Some empirical tests. In M. C. Jensen (Ed.), Studies in the theory of capital markets (p. 52). New York: Praeger.

Chen, C., \& Steiner, T. (1999). Managerial ownership and agency conflicts: A nonlinear simultaneous equation analysis of managerial ownership, risk taking, debt policy, and dividend policy. Financial Review, 34 (1), 119136. http://doi.org/10.1111/j.1540-6288.1999.tb00448.x

Chong, A., Guillen, J., \& Lopez-de Silanes, F. (2009). Corporate governance reform and firm value in Mexico: an empirical assessment, Journal of Economic Policy Reform, 12 (3), 163-188. http://doi. org/10.1080/17487870903105346

Demsetz, H. (1983). The structure of ownership and the theory of the firm. Journal of Law and Economics, 26 (2), 375-390. http://doi.org/10.1086/467041

Demsetz, H., \& Lehn, K. (1985). The structure of corporate ownership: Causes and consequences. Journal of Political Economy, 93 (6), 1155-1177. http://doi.org/10.1086/261354

Durán, R. F., Belén Lozano, M. \& Yaman, S. (2016) Is family control relevant for corporate cash holding policy?, Journal of Business Finance \& Accounting, 43 (9-10), 1325-1360, http://doi.org/10.1111/jbfa.12222

Fernando, G. D., Schneible, R. A., \& Suh, S. (2014). Family firms and institutional investors. Family Business Review, 27 (4), 328-345. http://doi.org/10.1177/0894486513481474

Frazzini, A., \& Pedersen, L. H. (2014). Betting against Beta. Journal of Financial Economics, 111 (1), 1-25. http:// doi.org/10.1016/j.jfineco.2013.10.005

Gompers, P., Ishii, J., \& Metrick, A. (2003). Corporate governance and equity prices. Quarterly Journal of Economics, 118 (1), 107-155. http://doi.org/10.2139/ssrn.278920

González, M., Guzmán, A., Pombo, C., \& Trujillo, M. A. (2015) The Role of Family Involvement on CEO Turnover: Evidence from Colombian Family Firms, Corporate Governance An International Review 23(3), 266284. http://doi.org/10.1111/corg.12083 
Grullon, G., Michaelv, R. \& Swaminathan, B. (2002) Are dividend changes a sign of firm maturity? Journal of Business, 75 (3), 387-424. http://doi.org/10.1086/339889

Holder, M. E., Langrehr, F. W. \& Lawrence Hexter, J. (1998) Dividend Policy Determinants: An Investigation of the Influences of Stakeholder Theory, Financial Management 27 (3), 73-82, http://doi.org/10.2307/3666276

Iwasawa, S., \& Uchiyama, T. (2014). The Beta anomaly in the Japanese equity market and investor behavior. International Review of Finance, 14 (1), 53-73. http://doi.org/10.1111/irfi.12023

Jensen, M. C. (1986). Agency costs of free cash flow, corporate finance, and takeovers. American Economic Review, 76 (2), 323-329. http://doi.org/10.2139/ssrn.99580

Jensen, M. C. \& Meckling, W. H. (1976) Theory of the firm: Managerial behavior, agency costs, and ownership structure. Journal of Financial Economics, 3(4), 305-360 http://doi.org/10.1016/0304-405X(76)90026-X

Kaiser, H. F. (1958). The varimax criterion for analytic rotation in factor analysis. Psychometrika, 23 (3), 187-200. http://doi.org/10.1007/BF02289233

La Porta, R., López-de-Silanes, F., Shleifer A., \& Vishny, R. (2000) Investor protection and corporate governance. Journal of Financial Economics 58(1-2) 3-27. http:/doi.org/10.1016/s0304-405x(00)00065-9

La Porta, R., López-de Silanes, F., Shleifer, A., \& Vishny, R. (2002). Investor protection and corporate valuation. Journal of Finance, 57 (3), 1147-1170. http://doi.org/10.1111/1540-6261.00457

Lin, C.-T. (2002). Dividend policies, legal regimes and institutional structures in the Asia Pacific Region. Asia Pacific Journal of Economics and Business, 6(2), 4-16. http://doi.org/http://business.curtin.edu.au/research/ publications/journals/apjeb/previous_issues.cfm

Lintner, J. (1965). The valuation of risk assets and the selection of risky investments in stock portfolios and capital budgets. Review of Economics and Statistics, 47 (1), 13-37. http://doi.org/10.2307/1924119

Manos. R. (2003) Dividend policy and agency theory: Evidence from Indian firms, South Asia Economic Journal, 4(2), 275-300. http://doi.org/10.1177/139156140300400206

Markowitz,H.(1952). Portfolio selection.Journal of Finance, 7 (1), 77-91.http://doi.org/10.1111/j.1540-6261.1952. tb01525.x

Mehran, H. 1992, Executive incentive plans, corporate control, and capital structure. Journal of Financial and Quantitative Analysis, 27 (4), 539-560. http://doi.org/10.2307/2331139

Miller, M. H. \& Modigliani F. (1961) Dividend policy, growth, and the valuation of shares, Journal of Business, 34 (4), 411-433. Retrieved June 20th, 2018 from https://www.jstor.org/stable/2351143

Miller, M. H. \& Rock, K. (1985), Dividend policy under asymmetric information. Journal of Finance, 40 (4), 10311051. http://doi.org/10.1111/j.1540-6261.1985.tb02362.x

Mossin, J. (1966). Equilibrium in a capital asset market. Econometrica, 34 (4), 768-783. http://doi. org/10.2307/1910098

Pearl, J. (2000). Causality: Models, reasoning, and inference. Cambridge University Press.

Rozeff, M. (1982). Growth, Beta and agency costs as determinants of dividend payout ratios. Journal of Financial Research, 5 (3), 249-259. http://doi.org/10.1111/j.1475-6803.1982.tb00299.x

Sharpe, W. F. (1964). Capital asset prices: A theory of market equilibrium under conditions of risk. Journal of Finance, 19 (3), 425-442. http://doi.org/10.1111/j.1540-6261.1964.tb02865.x

Treynor, J., \& Black, F. (1976). Corporate investment decisions, modern developments in financial management. New York: Praeger.

Valencia Herrera, H. (2009). Prácticas de gobierno corporativo. In H. Valencia Herrera (Ed.), Mejores prácticas financieras de las empresas en México (p. 93-111). Mexico: Instituto Mexicano de Ejecutivos de Finanzas. 